\title{
ANALYZING SUSTAINABLE COMPETITIVE ADVANTAGE: STRATEGICALLY MANAGING RESOURCE ALLOCATIONS TO ACHIEVE OPERATIONAL COMPETITIVENESS
}

\author{
Nurul Aida Abdul Malek ${ }^{1,2}$, Khuram Shahzad ${ }^{2}$, Josu Takala², \\ Stefan Bojnec ${ }^{3}$, Drago Papler ${ }^{3}$, Yang Liu ${ }^{2}$ \\ ${ }^{1}$ Universiti Tun Hussein Onn Malaysia (UTHM), Malaysia \\ ${ }^{2}$ Department of Production, University of Vaasa, Finland \\ ${ }^{3}$ Faculty of Management, University of Primorska, Slovenia
}

Corresponding author:

Nurul Aida Abdul Malek

Department of Production

University of Vaasa

Wolffintie 34, 65200 Vaasa, Finland

phone: (+358) 451809585

e-mail: aida.abdmalek@gmail.com

Received: 4 September 2015

Accepted: 14 September 2015

\section{AbSTRACT}

In today's dynamic business environment, a key challenge for all companies is to make adaptive adjustments to their manufacturing strategy. This study demonstrates the competitive priorities of manufacturing strategy in hydro-power case company to evaluate the level of sustainable competitive advantage and also to further analyze how business strategies are aligned with manufacturing strategies. This research is based on new holistic analytical evaluation of manufacturing strategy index, sense and respond, and sustainable competitive advantage models. These models help to describe, evaluate, and optimize resource allocation to meet the performance requirements in dynamic decision making. Furthermore, these models evaluate operational competitiveness for manufacturing strategies according to the multi-criteria priority. The results show that the adjustments of competitive priorities in manufacturing strategies by implementing the proposed holistic analytical models are helpful in strategically managing business operations. The discussion derives the most critical attributes in business operations while alignment of resource allocation with competitive priorities help to strategically focus those attributes. In conclusion, we argue that resource allocation and manufacturing strategies have become the most important capabilities in a business environment where companies focus to get a sustainable competitive advantage.

KEYWORDS

sustainable competitive advantage, sustainable operations, competitive priorities, sense and respond, manufacturing strategy index, adaptive strategy.

\section{Introduction}

European Union (EU) has embedded the aim to improve energy efficiency, reduce emissions and to raise the share of renewable energy significantly by 2020 as compared to 1990 to effectively balancing the economic development and environmental performance. In this global economic development era, manufacturing enterprises are trying to develop their competitiveness to survive and be stable. During the last two decades, this increased global competi- tion and recent developments in product and process technologies have enhanced the interest of manufacturing firms to focus on their core competencies and manufacturing strategies [1]. Relatively, the energy market has been deregulated to encourage competition along with sustainable development and therefore, the production of energy has been evoked to engage in a free market environment. It has been mentioned the benefits of decentralized electricity generation ranging from economic benefits, ecological benefits as well as improvement of sustainability 
$[2,3]$. However, the distribution network of the energy is still operating in a natural monopoly where Energy Market Authority (EMA) is monitoring the transparency of network service pricing.

In this situation, firms need to syndicate forwardthinking strategies into their operations to sustain in future competitive environment under vibrant and complex business circumstances [4]. Moreover, firms need to holistically employ dynamic and multifocused strategies into their business operations and decision-making process. For that reason, firms are more eager to think about competitive priorities that are significantly critical to perform a role of connection among business strategies and manufacturing objectives [1, 4]. However, innovation and services have also been included in the manufacturing strategy range in modern studies [5-7].

Manufacturing strategy is typically driven by the overall business strategy of the organization and designed to maximize the effectiveness of production and support elements while minimizing costs [8]. Competitive priorities can help companies to analyze their category competence development in comparison with global context and the level of supported business strategies, as well as manufacturing objectives [4, 9]. Therefore, a manufacturing strategy based on a business strategy includes three objectives as follows: competitive priorities, manufacturing objectives and action plans [10].

This study theoretically builds a resource-based assessment of the case companies where resourcebased strategies are discussed. A resource refers to tangible or intangible assets owned by a company at a specific point of time that will give them strengths or weaknesses in the market they are competing in [11]. According to [12], there are four company strategy groups; 1) prospector, 2) analyzer, 3) defender, and 4) reactor, where reactor is not significant and consistent. Similarly, according to [10], firms can calculate the global operative competitiveness in each above mentioned strategy group through their proposed analytic calculation model to different multi-criteria weights for quality, cost, time, and flexibility.

As an associate member of EU, the enforcement of deregulation of energy market has been undertaken gradually since 1999 in Slovenia [13]. [14] founds the deregulation has given some impacts on the dynamics of market competition and demand different management approach as well as quality of service in the supply chain management among electricity providers in Slovenia. Prior to the enforcement, there were five regional electricity distribution enterprises in Slovenia. The main focus of this paper is Electro
Gorenjska Kranj which holds $10 \%$ of electricity market share. They are implementing hydro-electricity production which is considered as green electricity production with electricity substitution from water resources reduces $\mathrm{CO}_{2}$ emissions from the nonrenewal sources of electrical energy such as coal [15]. Although they are remaining the most significant in their region, this amount has been declining reflected from the addition of competitors into the market.

The objectives of this paper are to analyze and evaluate major competitive priorities and to propose how to improve company's operational performance and competitiveness by answering the following research questions:

1. What kind of competitive priorities and manufacturing strategies are utilized by companies in free market conditions to design their operations?

2. Which are highly focused competitive priorities and adopted manufacturing strategies in past and future?

3. Which critical attributes have to be improved in order to increase the overall operational competitiveness?

Moreover, the focus is to showcase the types of manufacturing strategies and competitive priorities by using different tools in Sense and Respond (S\&R) method. This study analyzes the sustainable competitive advantage (SCA) in business units of case company and how the business strategies are supported by the manufacturing strategies. To achieve the set targets, different tools: the Manufacturing Strategy Index (MSI) and Normalized Scaled Critical Factor Index (NSCFI) were calculated. Most importantly, NSCFI has not been tested widely and very few case studies have been published previously [16-18]. Moreover, this study enhances the scope of research conducted by [19] which highlighted the need to examine these models in new business situations. Thus, this study contributes to quantify these established models in hydro-power case company to provide new discussion point of view in academia.

For this purpose, the following assumptions are set for the objectives study and to find out the required results. First, due to the transitions from monopolized market to free market among energy providers in Slovenia, we assume that all business units of this case company are moving towards analyzer strategy group that focuses on flexibility and gives a balanced weight to cost, quality, and time. Secondly, the distribution unit (sales) is following the best from a new strategy point of view of free market due to a small gap between the company and their customers or stakeholders along the supply chain. 
Therefore, we assume that they understand the market orientation better and react accordingly in their strategy development.

\section{Theoretical research background}

In the compound and dynamic business environment, companies need to rely on progressive business strategies for future competitiveness of business operations. Companies should focus more on dynamic business straggles holistically in their operations based on their business objectives. Therefore, competitive priorities have a significant bridging role between manufacturing objectives and business strategies [20]. In the same vein, sustainable competitive advantage has become an important critical factor in business operations by implementing a value creating strategy [21]. Furthermore, [22] argued that success of a firm hides in the balance between capabilities and resources that can be utilized to get a competitive advantage.

[23] argued that social, economic, and environmental factors are significant in sustainable development of energy concepts. [24] introduced the initial idea of sustainable competitive advantage (SCA) in the form of SWOT (strength, weakness, opportunity, threat) analysis to enhance the internal strengths and demolish the weaknesses. Later, [25] proposed a generic strategy which is based on the overall cost leadership, differentiation, and segmentation. Due to the extremely dynamic and turbulent business environment, this strategy was not applicable enough [26]. Thereafter, a resourcebased view concept was presented in this dynamic and turbulent business environment to get a competitive advantage. A resource-based view presents and explores the resource side of firms by studying firm's resources more than the product side [11]. He proposed resource-product matrices in his study that are useful tools to analyze the firm's resources and highlight the most significant resources to get a competitive advantage. According to [11], resources can be anything that causes strength or weakness of firms. Meanwhile, [21] claimed that resources of firms are rare and they are not only source of competitive advantage, but also to avoid threats. In this competitive, dynamic, and turbulent environment, firms behave differently in situations and use their possible resources to achieve sustainable competitive advantage. For that reason, operations or manufacturing strategy, competitive priorities, and types of organizational adaptation need to be addressed in firm's operations.

\section{Competitive priorities and operations/manufacturing strategy}

Competitive priorities are important and decisive variables for operation manager to better manage the global manufacturing issues [27]. The effectiveness of an operations strategy is determined by the degree of consistency between emphasized competitive priorities and corresponding decisions regarding operational structure and infrastructure [28]. Therefore, competitive priorities are mostly decided during the first phase of the development of manufacturing strategies to act as a link between the overall aim of the company and manufacturing objectives. According to [29], there are four types of competitive priorities that a company can choose from, depending on the type of market that they are serving, which are: Quality (Q), Cost (C), Time/Delivery (T) and Flexibility $(\mathrm{F})$.

[9] focused on the analysis of environmental management as new competitive priorities in business operations. They found that environmental management can also affect the four types of competitive priorities positively. In addition, studies on supply chain management suggested that these four priorities can be narrowed down into two groups: efficiency and responsiveness. Typically, these groups produce predictable demand of products with long shelf life. The second group is also referred as agile supply chain, which concentrates at quick and fast deliveries. Therefore, this type of supply chain focuses on two competitive priorities; flexibility and time. On the other hand, quality is also prioritized in both types of supply chains.

Operations strategy has been a topic of experiential study for 25 years. There are two different models that explain the link among competitive priorities: 1 ) the traditional trade-off model, and 2) the cumulative model [27]. Generally, operations strategy can be measured as companies' importance on specific competitive capabilities like cost, delivery, flexibility, and quality. These objectives explain manufacturing operations of the firm. However, in current studies, two more capabilities have been added, i.e. innovation and services in the range of operations strategy [5-7]. Moreover, adjustments in manufacturing strategies can be the result of improved operational competitiveness [10]. Green manufacturing strategy has not only becomes crucial in getting competitive advantage, but also contributes to the application of sustainable development philosophies [30].

Recently, the concept of strategy has been evolved adequately, which involves other aspects of it. The approach of strategy recognition and selection has been established because of the rapid 
change of the business environment, which allows organizations to grab the strategic idea and planning more firmly [31]. Furthermore, responsiveness, agility and leanness (RAL) possess a significant challenge for holistic and multi-focused strategies. Three dimensions of RAL model explain the characteristics of each aspect, i.e. $\mathrm{R}$ - responsiveness covers the unexpected requirements, whereas $\mathrm{A}$ - agility deals with optimal cost structure and $\mathrm{L}$ - leanness reduces waste in all activities and resources [32]. Hence, manufacturing strategy is based on a set of considerations including future plans, arrangement of performance, evaluating position in market, and a perception to overview the business activities and evaluate the competitors [33].

Moreover, [34] proposed conceptual framework where the focus was to analyze sustainability strategies from an innovation perspective. His framework provided three implementation strategies aligned with sustainability: resign, offensive, and defensive. Similarly, [35] discussed "defensive" and "offensive" strategies in their study where the argument was developed based on these strategies. They argued that firms implement defensive strategy when supplier management for risks and performance is required and offensive strategy is implemented when supply chain management for sustainable products is required in their operations. [36] created value and strategic success by presenting a dynamic framework for implementing sustainability. They distinguished internal and external strategies based on the current and future operations.

\section{Types of organizational adaptation}

While discussing how an organization can adapt to an uncertain and constantly changing business environment, [12] study led to the development of the adaptive cycle model. Their discovery shows that top management choices and decisions also have great impacts on the company's strategy. They however argued that the strategic-choice approach explains the organization's perceptions of environmental conditions and the decisions it makes in with coping these conditions [12]. There are four strategic types of organizations, namely defenders, analyzers, prospectors, and reactors [12]. 1) Defenders have narrow product-market domains. According to [20], the most important factor in defender strategy is cost as it relates to the competitiveness ranking of quality, cost, time and flexibility. 2) Analyzers use formalized structures and techniques to operate in a stable product-market domain but in changing environments, they look out for innovative ideas from their competitors and quickly adopt the most promising ones. In the competitiveness ranking of quality, cost, time and flexibility, analyzers focus mainly on flexibility, which gives them a balanced focus on cost, quality and time [20].

Meanwhile, 3) prospectors are organizations which continually seek to carry out research in developing new and innovative products. Considering the quality, cost, time and flexibility competitiveness ranking, prospectors are known to focus mainly on the quality [20]. Lastly, 4) Reactors: according to [12], changes and uncertainties are perceived in the reactor organizations, but their top management are unable to respond effectively until they are compelled by environmental pressures. Hence, due to their highly unstable structure, reactors change over time to one of the other three groups [37].

Table 1

Definitions of variables for critical success factors and manufacturing strategies (adapted from [38]).

\begin{tabular}{c|l}
\hline Variables & \multicolumn{1}{c}{ Definitions } \\
\hline $\mathrm{Q}$ & $\begin{array}{l}\text { The weight of quality in manufacturing strat- } \\
\text { egy or resource allocation }\end{array}$ \\
\hline $\mathrm{C}$ & $\begin{array}{l}\text { The weight of cost in manufacturing strategy } \\
\text { or resource allocation }\end{array}$ \\
\hline $\mathrm{T}$ & $\begin{array}{l}\text { The weight of time/delivery in manufacturing } \\
\text { strategy or resource allocation }\end{array}$ \\
\hline $\mathrm{F}$ & $\begin{array}{l}\text { The weight of flexibility in manufacturing } \\
\text { strategy or resource allocation }\end{array}$ \\
\hline $\mathrm{P}$ & $\begin{array}{l}\text { Competitiveness index of manufacturing strat- } \\
\text { egy (MSI) or resource allocation (RAI) in } \\
\text { prospector group }\end{array}$ \\
\hline $\mathrm{D}$ & $\begin{array}{l}\text { Competitiveness index of manufacturing strat- } \\
\text { egy (MSI) or resource allocation (RAI) in an- } \\
\text { alyzer group }\end{array}$ \\
\hline & $\begin{array}{l}\text { Competitiveness index of manufacturing strat- } \\
\text { egy (MSI) or resource allocation (RAI) in de- } \\
\text { fender group }\end{array}$ \\
\hline
\end{tabular}

\section{Analytical model development}

The term sense and respond ( $\mathrm{S} \& \mathrm{R})$ as a business concept first appeared in the article by [39]. The S\&R thinking was developed by [40] and [41] to analyze dynamic business strategies [42]. S\&R model is a business management concept used by organizations to analyze applicable strategies for rapidly changing business structures. The ability to quickly adjust the processes will be a decisive factor in the concurrent economy [42]. The main outcome of this method is to provide signals so that companies can react accordingly based on the "traffic lights" indicator given by the result. Red, yellow and green bars indicate the status of each attribute. Red represents critical attributes which require immediate attention from companies. Yellow signifies potentially critical 
attributes which may or may not be critical in the future and the green indicates the non-critical attributes.

The S\&R thought was utilized by [43] to develop the operative management system by introducing critical factor index (CFI) [42]. Based on the CFI introduction, the S\&R model has undergone four improvement stages from CFI to Balanced BCFI to SCFI and NSCFI. Generally, the aim of each model is similar, which is to calculate the status of each attribute understudied. The four-stage models have common parts as part of the equation and different parts as numerator. The CFI was introduced by [43] for the first time to interpret and evaluate the critical factors of strategic adjustment, which can support the strategic decision-making phase. The BCFI was developed by [44] based on the principle of the CFI model. On the other hand, the SCFI model was discussed and developed by [42] which further tested and published by [16-18]. Along with the study, a new S\&R model, named NSCFI, was developed based on previous models [16]. For this reason, this study uses NSCFI model that has not been tested widely, and very few case studies have been published previously. Furthermore, this model has proven to generate results which reflect the real situation [38].

The analytical models for manufacturing strategy are used to calculate the operational competitiveness indexes of companies in different competitive groups, namely prospector, analyzer and defender [12]. The theory of analytical models is subsequently described by four main criteria: cost, quality, time and flexibility. Based on the analysis of the four main criteria, the manufacturing strategies are analyzed. The methods of calculating the priority weights as well as manufacturing strategy indexes are adopted through [38].

Table 2

Definitions of variables (adapted from [38]).

\begin{tabular}{c|l}
\hline Variables & \multicolumn{1}{c}{ Definitions } \\
\hline CFI & $\begin{array}{l}\text { The old model (critical factor index) which } \\
\text { measures the level of resource allocations in } \\
\text { the defined attributes }\end{array}$ \\
\hline BCFI & $\begin{array}{l}\text { The old model (balanced critical factor index) } \\
\text { which measures the level of resource alloca- } \\
\text { tions in the defined attributes }\end{array}$ \\
\hline SCFI & $\begin{array}{l}\text { The old model (scaled critical factor index) } \\
\text { which measures the level of resource alloca- } \\
\text { tions in the defined attributes }\end{array}$ \\
\hline NSCFI & $\begin{array}{l}\text { The new model (normalized scaled critical fac- } \\
\text { tor index) which measures the level of resource } \\
\text { allocation in the defined attribute }\end{array}$ \\
\hline
\end{tabular}

\section{Sustainable competitive advantage}

The concept of competitive advantage has been significantly discussed over the last three decades [45, 46]. He argued that competitive global business approaches are grounded on differentiation by distinctive knowledge of product's quality and technology. The notion of excellence in the business world provides a foundation for a dynamic competitiveness, which is a source of sustainable competitive advantage [47, 48]. Similarly, manufacturing managers have a key role in achieving superior competitive performance by actively participating in strategic planning processes [49, 50]. [11] and [21] originated sustainable competitive advantage based on the attributes of resources and capabilities, while [51] contemplated certain manufacturing competitive priorities and dynamic capabilities along with unique decision strategies for achieving a sustainable competitive advantage.

Sustainable competitive advantage is a business strategy based on firm's resources that support firms to sustain their competitive advantage by outperforming others in a competitive market [52]. [53] argued that employing customer oriented business strategies by exploiting unique competences and resources bring a sustainable competitive advantage for firms. Close relationships with suppliers, customers, and employees enable firms to rationalize their business strategies in favor of firm's competitive advantage. Moreover, sustainable competitive advantage is a concept of achieving financial and market benefits, and distinctive dynamic capabilities which has emerged as a vital research field [54-56]. Recently, several researchers have identified the significance of sustainable competitive advantage as a source of developing core capability, knowledge sharing, market innovation, global resources, and most importantly positive psychological capital and vice versa [57-62]. Keeping these important factors into consideration identified by researchers, this study implement SCA to identify the significant factors that help companies not only to enhance their performance but also sustain the best manufacturing strategies to get a competitive advantage.

The SCA analysis provides a clear view for the management of companies to prioritize their manufacturing strategy to get a competitive advantage. It explains the risk probability, where case companies might have to consider changing the manufacturing strategy in different competitive groups, namely prospector, analyzer, and defender. Sustainable competitive advantage (SCA) results are obtained from the integrated MSI and S\&R results of the study. To achieve the necessary level of reliability of the 
results, three methods of validation (i.e. MAPE: Absolute Percentage Error, RMSE: Root Mean Squared Error, and MAD: Maximum Deviation) are utilized to ensure a moderate level of reliability in the results. The equations for calculating risks are obtained from Takala et al. [17].

\section{Research methods}

This paper consists of a case study based on hydro-power integrated supply chain in Slovenia. This well-known group operates in electricity chain which ensures the production, network, and distribution of electricity in the northwestern part of Slovenia. These business units are controlled by Electro Gorenjska Kranj within the company. Producing electricity from hydro power has become a quite important necessity and cost-effective system of energy technology considering the economic, social, and environmental factors [63]. The aim of the production unit is to improve and maintain their current operations including their facilities and human resources. Furthermore, network unit focuses on providing quality, punctual and cost-efficient operations in delivering their service to end customer. Overall, the network unit is also aiming to actively participate with various activities that encourage sustainable development opportunities in Slovenia. Distribution unit focuses on improving the cost performance of the company including in attaining favorable purchase price of the electricity.

Methodologically, this research employs constructive research approaches which focusing on solving problems through innovative constructions and simultaneously contributes to the related field of study where it is applied [64]. The suggested innovative constructions are also attempted to be tested to see the relevancy of its applicability. For this study, the innovative constructs is the integrative holistic system for the identification of critical attributes and manufacturing strategy. The results generated from the models would be validated by the case company as a weak market test. If they are satisfy with the result obtained, further actions for improvement will take place.

This research approach involves close participation between practitioners and researchers in order to appropriately identify the actual problem and propose the fitting solution as well as to achieve rich descriptions to the scope of research and also best contributing to the related knowledge field [65]. Therefore, this company was chosen to be the case company of this study due to the close collaboration between research authors and management of the company. By reason of the complexity of data collection procedure, it is crucial for the researchers to have a close link with the respondent to assure the quality and reliability of the data collected. It is also significant to make sure the respondents understand the instructions and questions listed in the questionnaire so that deep and meaningful analysis can be performed. Moreover, the experts and developers of these models are also involved in this study, which increases the validity of data analyzing.

\section{Data collection and data analysis}

Data collection for the research is tied particularly to the method being undertaken. The general method used for the research was by sending out web-questionnaires to managers of the top levels and operational levels in the business units in November 2013. Questionnaires containing percentage value of multi-criteria priority weights were sent to top level management. The head of each business unit responded with their answers according to their own evaluation towards each business unit's strategy. Questionnaires containing organizational competences by [43] comprising four categories; knowledge and technology management, processes and workflows, organizational systems and information systems were sent to operational level managers of each business unit. Thirteen respondents answered our questionnaires comprising: five from the production unit, four from the network unit, and four from the distribution unit. All of these 13 respondents have sufficient knowledge about the operations of the company and are decision makers or at least working in middle management group. In total, there are 21 attributes that are further categorized into four types of competitive priorities; quality, cost, time and flexibility. It also shows the deviations of experiences and expectations. Table 1 contains the questionnaire sample used in this study.

Table 3

Questionnaire sample.

\begin{tabular}{l|c|c|c|c|c|c|c|c}
\hline & Expectations & Experiences & \multicolumn{2}{|c|}{ Direction of development } & \multicolumn{3}{|c}{ Development experience } \\
\hline Attributes & $(1-10)$ & $(1-10)$ & Worse & Same & Better & Worse & Same & Better \\
\hline $\begin{array}{l}\text { Attribute 1 } \\
\text { Attribute 2 }\end{array}$ & & & & & & & & \\
\hline
\end{tabular}


Table 4

Definitions of variables used in the study (adapted from [38]).

\begin{tabular}{|c|c|}
\hline Variables & Definitions \\
\hline Expe-riences & $\begin{array}{l}\text { The level of experiences in a scale of } \\
1-10 \text { in the defined duration }\end{array}$ \\
\hline Expecta-tions & $\begin{array}{l}\text { The level of expectations in a scale of } \\
1-10 \text { in the defined duration }\end{array}$ \\
\hline Better, worse & $\begin{array}{l}\text { The trend of the development situ- } \\
\text { ation in a choice of better, same or } \\
\text { worse in the defined duration. The } \\
\text { counts of 'better' and 'worse' are de- } \\
\text { rived into percentage weights }\end{array}$ \\
\hline Perfor-mance index & $\begin{array}{l}\text { Measures the average of experiences } \\
\text { scaling between } 0 \text { and } 1 \text {, and the larg- } \\
\text { er value means a better performance } \\
\text { experience of the attribute }\end{array}$ \\
\hline Impor-tance index & $\begin{array}{l}\text { Measures the average of expectations } \\
\text { scaling between } 0 \text { and } 1 \text {, and the larg- } \\
\text { er value means a more important ex- } \\
\text { pectation of the attribute }\end{array}$ \\
\hline Gap index & $\begin{array}{l}\text { Measures the gap between experi- } \\
\text { ences and expectations. The value } 1 \\
\text { means that there is no gap; the value } \\
\text { above } 1 \text { means that experiences are } \\
\text { lower than expectations and the val- } \\
\text { ue below } 1 \text { means that experiences } \\
\text { are higher than expectations }\end{array}$ \\
\hline Develop-ment index & $\begin{array}{l}\text { Measures the direction of develop- } \\
\text { ment compared to the old situations. } \\
\text { The value } 1 \text { means that performance } \\
\text { remains on the same level; the val- } \\
\text { ue above } 1 \text { means that performance } \\
\text { is going worse and the value below } 1 \\
\text { means that performance is going bet- } \\
\text { ter }\end{array}$ \\
\hline MSI & $\begin{array}{l}\text { Competitiveness indexes of manufac- } \\
\text { turing strategy in prospector, analyz- } \\
\text { er and defender groups }\end{array}$ \\
\hline RAI & $\begin{array}{l}\text { Competitiveness index of resource al- } \\
\text { location in prospector, analyzer and } \\
\text { defender groups }\end{array}$ \\
\hline $\mathrm{SCA}$ & $\begin{array}{l}\text { The final evaluation results indicat- } \\
\text { ing the sustainability level of the } \\
\text { competitive advantage during the } \\
\text { measured period. }\end{array}$ \\
\hline
\end{tabular}

\section{The overall flow of data collection and data analysis}

The analysis of the data starts with a descriptive analysis where the percentage given by the top management is carefully evaluated to set the weight of each competitive priority based on their point of view. This result will be used again later as an input for a later part of the analysis.

Consequently, the analysis is going deeper by analyzing the data given by the operational level by using S\&R model which is NSCFI. As mentioned in the literature, NSCFI is the latest and improved analytical models in the $\mathrm{S} \& \mathrm{R}$ analysis to evaluate com- petitiveness of a company based on past and future resource input levels. The model has proven to generate result that best reflect the actual situation $[18$, $38,66]$. For this research, NSCFI will measures competitive priority weighting according to resource allocations scale assessed by the informants correspondingly for all business units. It generates resource allocation indexes for all 21 attributes and these indexes were then accumulated according to their competitive priority group so that the allocations can be seen at the priority group level both in past and future respectively.

Based on that, deviations from past to future values are calculated to acquire the trend of changes in resource allocations. In order to identify the status of each attributes, they are evaluated individually based on resource allocation indexes by generated by NSCFI. High value indicates over resourced whilst low value demonstrates the opposite. Other than that, the attribute is considered to be at a satisfactory level. Additionally, the development trend of each attribute from past to future was analyzed. The interest is to seek for attribute with worse trend which requires further improvement from organization's side. The trend is evaluated based on the following conditions; (1) if the attribute's status is satisfactory in both past and future, the trend is considered to be unchanged and marked with "-", (2) if the attribute's status changes from satisfactory to either over resourced or low resourced, it means the trend is going worse development and (3) if the status change from either over resourced or low resourced to satisfactory, the trend is in better development. Essentially, the results generated from NSCFI were folded in various layers and the interpretation has been done for each layer to establish valuable conclusions as well as providing the most benefit to the case company.

In order to identify the type of strategy orientation adopted by each business unit, their operational competitiveness indexes are calculated. The indexes are generated by respective analytical model for prospector, defender and analyzer. The main inputs for these analytical models derived from the weights of $\mathrm{Q}, \mathrm{C}, \mathrm{T}$ and $\mathrm{F}$ given by the top management as well as those calculated by NSCFI. In regards to that, there are two main outcomes generated from the analytical models. They are: (1) the numeric values that represent each strategy group from top management's point of view which to be defined as MSI while the other one is (2) the numeric values that represent each strategy group from resource allocations point of view which to be defined as RAI. The strategy type with the highest calculated value is as- 
sumed to be adopted by the corresponding business unit. The MSIs and RAIs were generated for both past and future periods and will be further analyzes to see the trend of changes through their deviations.

Ultimately, the analysis continues with SCA analysis where the consistency of manufacturing strategies (MSI) and resource allocations (RAI) are evaluated. To achieve this aim, the evaluation was performed based on the results generated by MAPE and RMSE. The validation results are in the range of 0 to 1 , where 1 indicates perfect consistency between the strategies developed in the past and future compared to the resources that have been or to be allocated. Therefore, high indexes represent good support of resource allocations in strategy implementation which is the key capability in achieving sustainable competitive advantage.

The following Fig. 1 summarizes the flow of data collection for data analysis.

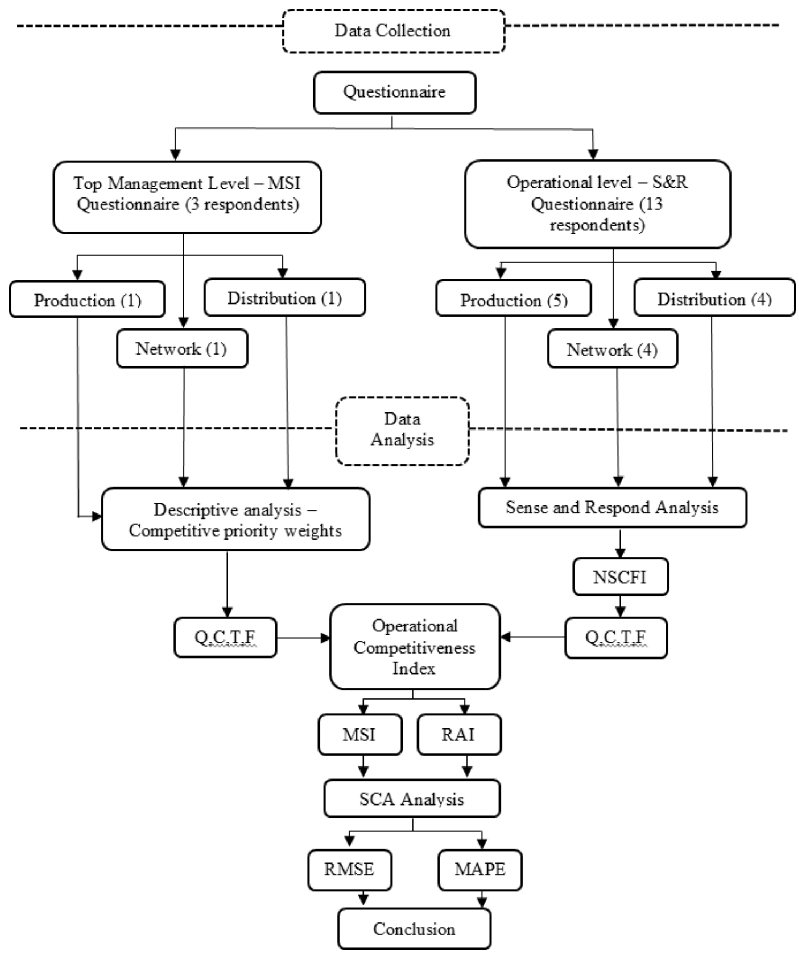

Fig. 1. The flow of the data collection and data analysis.

\section{Analysis results}

Figure 2 shows the percentage of deviation of multi-criteria priority weights of Q (Quality), $\mathrm{C}$ (Cost), $\mathrm{T}$ (Time) and $\mathrm{F}$ (Flexibility) from past to future based on top management. The data given by the informants is fully based on their subjective assessment of the company's strategy. The deviation reflects the decision where the resources should or should not be allocated in the future period. Based on these decisions, the positioning of the company in the market can be determined by defining their preference competitive priorities which ultimately indicates their manufacturing strategy. Positive deviation means the resources allocated for a particular competitive priority are increased. On the other hand, negative deviation means the resources allocated are decreased.

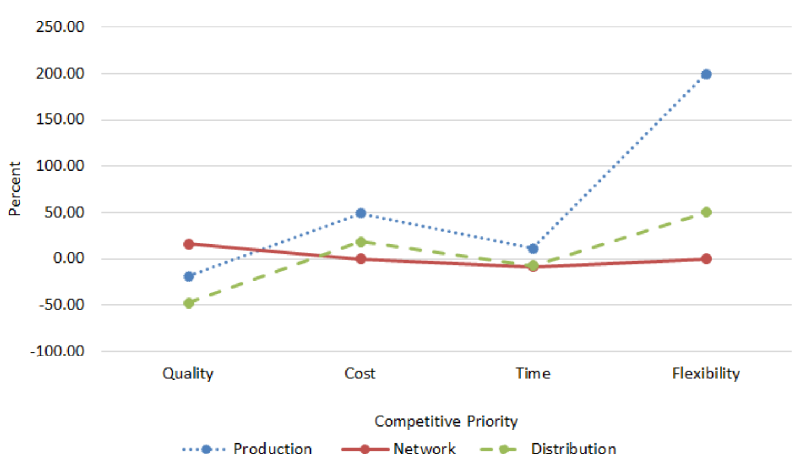

Fig. 2. Percentage of deviation of multi-criteria priority weights from past to future.

The result shows the priority that is expected to be improved according to the opinions of the top management for each unit. Negative or zero deviation shows that a particular priority does not need further additional resources as they are good at present. From Fig. 2, it can be seen that the highest increase in resource allocation for both production and distribution units is flexibility. The calculated sum of resource allocation for each priority and business unit demonstrate that the production unit is focusing on quality while the distribution unit is focusing on cost. However, the deviations show both are mostly increasing the allocation for flexibility. On the contrary, the network company is assigning most of their resources in time but the deviation values indicate that they are increasing the portion for quality and reducing time.

Based on the sense and respond method, NSCFI model generate results that demonstrate the direction of development from past to future values of resource allocation among competitive priorities under this study. From this result, the overall concentration of resource allocation in past and future is defined in each unit. Figure 3 points out the percentage of deviations of multi-criteria priority weights of $\mathrm{Q}, \mathrm{C}, \mathrm{T}$ and $\mathrm{F}$ from past to future based on the results calculated by NSCFI models. 


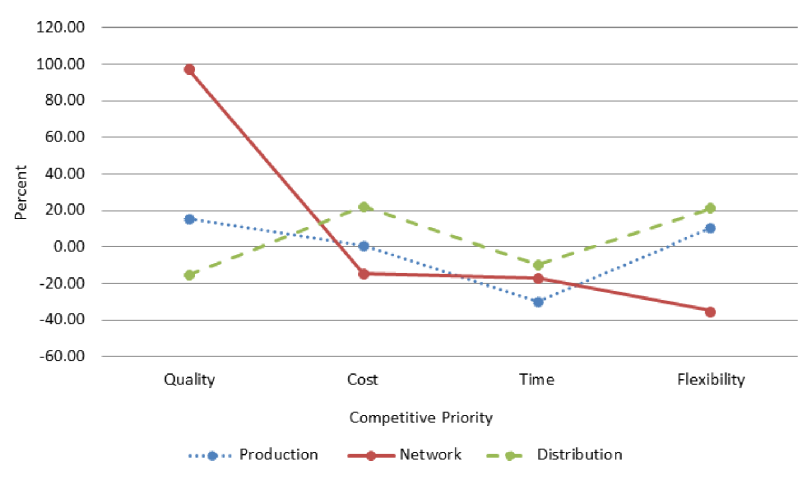

Fig. 3. Percentage of deviations of multi-criteria priority weights from past to future based on NSCFI models.

In the production unit, the overall result reveals that they are focusing on flexibility. However, the deviation values show that they are putting more resources into quality. Nevertheless, the amount of deviation among other competitive priorities is low and this indicates the allocations are almost balance to all priorities with the lowest amount assigned to time. On the other hand, past NSCFI values show that the network unit is focusing on flexibility but shifting to quality in the future. The deviation figure supports this by showing the highest values in quality. Meanwhile, both past and future values indicate that the distribution unit is concentrating on quality. Yet, at the same time, they are attempting to improve their flexibility as well by having high value of deviation in this priority.

To highlight the main finding of sense and respond's analysis, the study has shortlisted the attributes with a worse trend development in each business unit. According to the evaluation, these attributes are critical and need further improvement on resource allocations to have a long-term success in the market they are competing in. These attributes are sent for weak market test accordingly to all business units. The results were presented and discussed and their feedbacks were collected and documented for verification. Table 5 shows the list of suggested critical attributes in detail and the attributes are categorized according to their business unit and competitive priority group for better focus in future improvement. Out of 21 attributes an- alyzed, six critical attributes were identified under production unit and nine from network and distribution.

As shown in Table 5, the production company consists of two critical attributes: 'quality control of products, processes and operations' and 'innovativeness and performance of research and development'. The first attribute belongs to the quality group while the latter is cost. The study suggests the production unit to pay attention to these two attributes due to the worse trend they had from past to future. Meanwhile, the study proposes three attributes for improvement in the network unit. The first two attributes are under cost group that are related to 'knowledge and technology diffusion' and 'code of conduct and security of data and information'. Another attribute is 'communication between different departments and hierarchy levels' which lies under the time group. Among all three units, the distribution unit consists of the most number of attributes from three different priority groups.

In sum, the study recommends seven attributes to be focused on. The first two attributes belong to the quality group: 'on-time deliveries to customer' and 'control and optimization of all types of inventories'. As the final units before they reach their customer, these two attributes play important roles to ensure the smooth flow of products to the end user. In the meantime, the next two attributes belong to the cost group. The study suggests more attention should be given to 'knowledge and technology diffusion' and 'reduction of unprofitable time in processes'. The last three attributes are under flexibility group; 'training and development of the company's personnel', 'short and prompt lead-times in order-fulfillment process' and 'well-defined responsibilities and tasks for each operation'.

Based from the feedbacks, all business units were agreed with results at the same level. Accordingly, some of the critical attributes identified were proven critical since they are already at improvement stages while one is completely solved. Therefore, the results are validated and reflect the real situation. 
Table 5

List of critical attributes under each business unit.

\begin{tabular}{|c|c|c|c|c|c|c|}
\hline & \multicolumn{2}{|c|}{ Production } & \multicolumn{2}{|c|}{ Network } & \multicolumn{2}{|c|}{ Distribution } \\
\hline & $\begin{array}{c}\text { Critical } \\
\text { attribute }\end{array}$ & Feedback & $\begin{array}{c}\text { Critical } \\
\text { attribute }\end{array}$ & Feedback & $\begin{array}{l}\text { Critical } \\
\text { attribute }\end{array}$ & Feedback \\
\hline \multirow[t]{3}{*}{ Quality } & $\begin{array}{l}\text { On-time } \\
\text { deliveries } \\
\text { to customer }\end{array}$ & $\begin{array}{l}\text { Agree about } \\
\text { services, while } \\
\text { electricity sup- } \\
\text { ply is on-time. }\end{array}$ & $\begin{array}{l}\text { On-time } \\
\text { deliveries } \\
\text { to customer }\end{array}$ & $\begin{array}{l}\text { Agree about } \\
\text { services, while } \\
\text { electricity sup- } \\
\text { ply is on-time. }\end{array}$ & $\begin{array}{l}\text { On-time deliver- } \\
\text { ies to customer }\end{array}$ & $\begin{array}{l}\text { Agree about } \\
\text { services. }\end{array}$ \\
\hline & $\begin{array}{l}\text { Quality control } \\
\text { of products, } \\
\text { processes } \\
\text { and operations }\end{array}$ & $\begin{array}{l}\text { Agree } \\
\text { (there are } \\
\text { complains } \\
\text { about } \\
\text { accounts) }\end{array}$ & $\begin{array}{l}\text { Usability and } \\
\text { functionality } \\
\text { of information } \\
\text { systems }\end{array}$ & $\begin{array}{l}\text { Agree as they } \\
\text { had problems, } \\
\text { but some } \\
\text { improvements } \\
\text { are with new } \\
\text { provider } \\
\text { of remote con- } \\
\text { trol } \\
\text { center. }\end{array}$ & $\begin{array}{l}\text { Control and op- } \\
\text { timization of all } \\
\text { types of inven- } \\
\text { tories }\end{array}$ & Agree. \\
\hline & - & & - & & $\begin{array}{l}\text { Usability and } \\
\text { functionality } \\
\text { of information } \\
\text { systems }\end{array}$ & $\begin{array}{l}\text { It is not } \\
\text { anymore } \\
\text { a problem. }\end{array}$ \\
\hline \multirow[t]{3}{*}{ Cost } & $\begin{array}{l}\text { Innovativeness } \\
\text { and perfor- } \\
\text { mance } \\
\text { of research } \\
\text { and develop- } \\
\text { ment }\end{array}$ & $\begin{array}{l}\text { Agree } \\
\text { (it is at } \\
\text { early stage) }\end{array}$ & $\begin{array}{l}\text { Knowledge and } \\
\text { technology dif- } \\
\text { fusion }\end{array}$ & $\begin{array}{l}\text { Partly disagree } \\
\text { due to some im- } \\
\text { provements. }\end{array}$ & $\begin{array}{l}\text { Knowledge and } \\
\text { technology dif- } \\
\text { fusion }\end{array}$ & $\begin{array}{l}\text { Agree about } \\
\text { marketing. }\end{array}$ \\
\hline & $\begin{array}{l}\text { Knowledge and } \\
\text { technology dif- } \\
\text { fusion }\end{array}$ & $\begin{array}{l}\text { Agree, but } \\
\text { there have been } \\
\text { improvements } \\
\text { in the meantime }\end{array}$ & $\begin{array}{l}\text { Leadership and } \\
\text { management } \\
\text { systems of the } \\
\text { company }\end{array}$ & $\begin{array}{l}\text { Agree with } \\
\text { market } \\
\text { developments. } \\
\text { Remote control } \\
\text { center has } \\
\text { brought some } \\
\text { improvements. }\end{array}$ & $\begin{array}{l}\text { Reduction } \\
\text { of unprofitable } \\
\text { time in } \\
\text { processes }\end{array}$ & Agree. \\
\hline & - & & $\begin{array}{l}\text { Code of conduct } \\
\text { and security of } \\
\text { data and infor- } \\
\text { mation }\end{array}$ & Agree. & - & \\
\hline Time & - & & $\begin{array}{l}\text { Communication } \\
\text { between differ- } \\
\text { ent departments } \\
\text { and hierarchy } \\
\text { levels }\end{array}$ & Agree. & $\begin{array}{l}\text { Availability } \\
\text { of information } \\
\text { in information } \\
\text { systems }\end{array}$ & Agree. \\
\hline \multirow[t]{3}{*}{ Flexibility } & $\begin{array}{lr}\text { Adaptation } & \text { to } \\
\text { knowledge and } \\
\text { technology }\end{array}$ & $\begin{array}{l}\text { Partly } \\
\text { disagree: they } \\
\text { have introduced } \\
\text { remote control } \\
\text { center, which } \\
\text { has substituted } \\
\text { employment }\end{array}$ & $\begin{array}{l}\text { Short and } \\
\text { prompt lead- } \\
\text { times in order- } \\
\text { fulfillment } \\
\text { process }\end{array}$ & Agree. & $\begin{array}{l}\text { Training and } \\
\text { development } \\
\text { of the compa- } \\
\text { ny's } \\
\text { personnel }\end{array}$ & $\begin{array}{l}\text { Agree. } \\
\text { Lack of } \\
\text { electrical } \\
\text { engineers. }\end{array}$ \\
\hline & $\begin{array}{l}\text { Well-defined } \\
\text { responsibilities } \\
\text { and tasks for } \\
\text { each operation }\end{array}$ & $\begin{array}{l}\text { Partly disagree: } \\
\text { on } 1 \text { January } \\
2015 \text { they have } \\
\text { introduced ISO } \\
\text { standard } 9001 \\
\text { with monitor- } \\
\text { ing input and } \\
\text { output flows } \\
\text { with project } \\
\text { organization. }\end{array}$ & $\begin{array}{l}\text { Adaptation } \\
\text { to changes in } \\
\text { demands and in } \\
\text { order backlog }\end{array}$ & $\begin{array}{l}\text { Agree due to } \\
\text { lack of coherent } \\
\text { approach. }\end{array}$ & $\begin{array}{l}\text { Short and } \\
\text { prompt lead- } \\
\text { times in order- } \\
\text { fulfillment } \\
\text { process }\end{array}$ & $\begin{array}{l}\text { Improvements } \\
\text { this year. }\end{array}$ \\
\hline & - & & $\begin{array}{l}\text { Well-defined } \\
\text { responsibilities } \\
\text { and tasks for } \\
\text { each operation }\end{array}$ & $\begin{array}{l}\text { Agree due to } \\
\text { present frag- } \\
\text { mentation. }\end{array}$ & $\begin{array}{l}\text { Well-defined } \\
\text { responsibilities } \\
\text { and tasks for } \\
\text { each operation }\end{array}$ & Agree. \\
\hline
\end{tabular}




\section{Sustainable competitive advantage (SCA) analysis}

In order to react to their environment, companies can be generally defined into four types of strategic groups: P: Prospector, A: Analyzer, D: Defender, and R: Reactor. The features of each strategy determine their positions in the market. Figure 4 shows the trend of strategy orientation among all business units according to their manufacturing strategy and resource allocations indexes respectively in past and future.

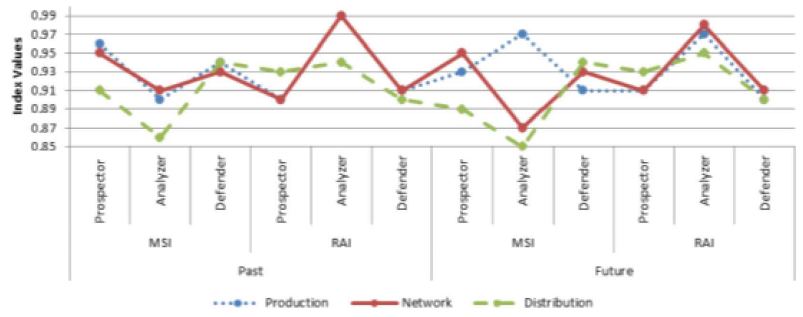

Fig. 4. Percentage of deviation from past to future strategy based on the results generated by MSI and RAI.

The MSI tendency for production describes their strategic focus was more on prospector in the past but shifted to analyzer in the future which leads this business unit from quality to flexibility orientation. The pattern is almost similar with their RAI's trend except for past period which they are more into analyzer instead of prospector. Nevertheless, future RAI indicates that they are moving towards the same strategic focus as the MSI. For network business unit, their aim is to be efficient in the quality of delivering their product and this influences the priority within their operations. MSI indicates concentration in prospector strategy both in past and future. On the other hand, the RAI in both time periods do not support the MSI by directing more into analyzer strategy. Similarly, distribution unit also does not support alignment as both periods indicate unmatched strategy type orientation between their MSI and RAI indexes. The manufacturing strategy is more in the direction of defender whilst the RAI lead to analyzer strategy.

Based from RAI values, it can be seen that all business units are tend to be in analyzer group both in past and future which is a strategy that balancing resource allocations toward all four competitive priorities and assumed to be less risky as all competitive priorities are supported equally. However, this approach is not competitive if the manufacturing strategies are intentionally developed to be directed into another type of strategy orientation which to better suit the market competition.
The SCA analysis is further elaborated in Fig. 5 where the percentages of deviation from the past strategy to future strategy for each model are taken into consideration. In this perspective, the amount of changes from past to future strategy based on the results generated by MSI and NSCFI are take into account and can be seen. The numbers along the line represent the amount of deviation in percentage values. Positive deviation means the values are increased from past to future. On the other hand, negative or zero deviation means the values are decreased or not shifting at all.

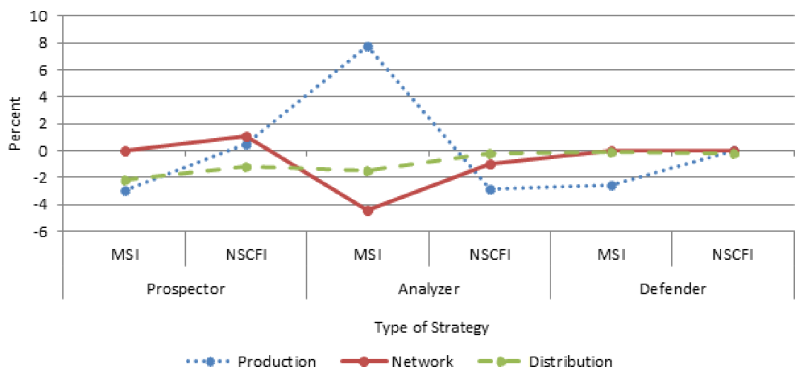

Fig. 5. Percentage of deviation from past to future strategy based on the results generated by MSI and NSCFI.

The overall results for both in past and future periods lead the production unit to the same strategy, which is analyzer. This is supported by the highest amount of deviation in the analyzer strategy. There is a possibility for the company to have minor features of prospector strategy as there is a slight positive increment in that category. Meanwhile, the network unit also seems to have the highest increment in the analyzer strategy. Nevertheless, their MSI values which represent responses from the top management show the opposite. This supports the overall results in the past and future period where MSI and NSCFI do vary in generating network's type of strategy. From the result found in SCA analysis, there is no absolute result on which type of strategy does the distribution unit belong to as each model leads to a different strategy. However, the deviation value indicates the highest increment is in the analyzer strategy with 5 percent changes. Nevertheless, this does not represent the actual strategy adopted by this unit.

The ultimate aim of this study is to evaluate operation strategy developed in the past and future against the resources that have been or to be allocated by the management of all business units. To achieve this aim, the evaluation was performed based on the results generated by MAPE and RMSE. The validation results are in the range of 0 to 1 , where 1 indicates perfect consistency between the strategies 
developed in the past and future compared to the resources that have been or to be allocated. Therefore, high indexes represent good support of resource allocations in strategy implementation which is a key capability in achieving sustainable competitive advantage.

The result calculated for the validation is illustrated in Fig. 6. Past and future indexes are expressed by the lines respectively to all business units based on MAPE and RMSE. The comparison highlights production as the dominant business unit in a right direction. Their future index's values are higher than the past index for both models which means their manufacturing strategy is sustainable and competitive. On the other hand, network and distribution unit do not show competitive result where the future values hold lower than past value. These indicate misalignments in relation to resource allocations and uncompetitive steer into the intended direction of their manufacturing strategy implementations.

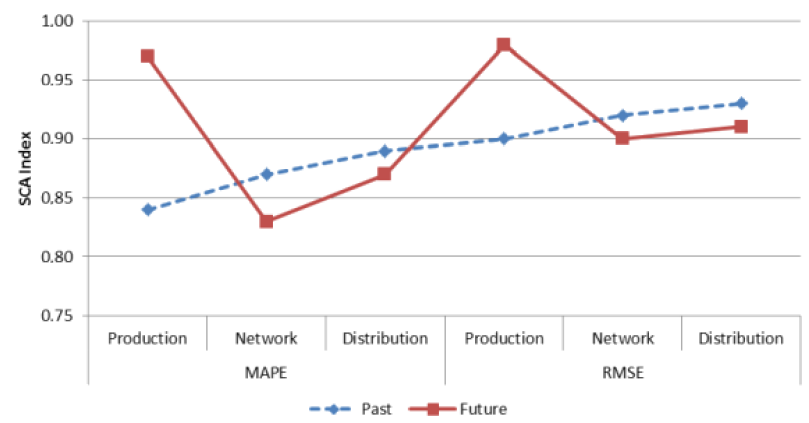

Fig. 6. Calculated validation based on MAPE and RMSE.

\section{Discussion}

In the following Table 6 , the summary of results according to the MSI and NSCFI (for three vertically integrated business units) is defined. The competitive priorities and strategy group for the case company are mentioned according to their operations in comparison to two methodologies (MSI and NSCFI).

Table 6

Competitive priorities for each company.

\begin{tabular}{c|c|c|c|c}
\hline & \multicolumn{2}{|c|}{ Past } & \multicolumn{2}{c}{ Future } \\
\hline & MSI & NSCFI & MSI & NSCFI \\
\hline Production & Quality & Cost & Quality & Flexibility \\
\hline Network & Time & Flexibility & Time & Quality \\
\hline Distribution & $\begin{array}{c}\text { Cost } \\
\text { and Delivery } \\
\text { (same weight) }\end{array}$ & Quality & Cost & Quality \\
\hline
\end{tabular}

Competitive priorities act as a link between the overall aim of the company and manufacturing activities. The competitive priorities of each unit have been identified in the analysis. The alignment of competitive priorities between the top management level and operational level management has been compared. This analysis is also aligned with one of the manufacturing strategy aspects ( $f i t$ ) identified by [67]. They identified strategic intent, focus, fit, and resource configuration to evaluate and configure them to get a competitive advantage. In this study, each business unit is categorized into the type of manufacturing strategy (past and future) based on the competitive priorities.

The result found by this study is consistent with the previous work done by $[16,17]$, which describes that NSCFI models are valid tools to perform such analysis that can assist managers to review their current strategy and further make decisions accordingly. Common vision towards strategy planned is crucial between the top level and operational level management to avoid resources to be misspent. Interestingly, the results show that competitive priorities between the top level and operational level management are not particularly aligned in all business units of case company. This suggests that the judgment of the company's representative towards their respective company's strategy is not in coherence with the resources allocated. It is suggested for managers to make adjustment accordingly in resources allocation to make sure in the future they are following the intended direction as planned [67]. The competitive landscape has now encouraged companies to compete not only on their own capabilities but also together with their entire supply chain. Therefore, it is crucial for each of the company's business unit within the supply chain to align their competitive priorities all across functional areas. We found very relevant results regarding competitive priorities that are aligned with the objectives of this study. Additionally, this study has also found that evaluating competitive priorities help to identify critical attributes that must be improved to enhance the overall operational competitiveness. These critical attributes are listed in Table 5.

The second main finding of the study discovered the strategy group of each company belongs to. The following Table 7 . shows the type of strategy group of each business unit in detail.

Table 7

Type of strategy group for each company.

\begin{tabular}{l|c|c|c|c}
\hline & \multicolumn{2}{|c|}{ Past } & \multicolumn{2}{c}{ Future } \\
\hline & MSI & RAI & MSI & RAI \\
\hline Production & Prospector & Analyzer & Analyzer & Analyzer \\
\hline Network & Prospector & Analyzer & Prospector & Analyzer \\
\hline Distribution & Defender & Analyzer & Defender & Analyzer \\
\hline
\end{tabular}


According to the SCA analysis, the production unit generally focuses on flexibility in implementing their manufacturing strategies during the transitions from monopolized market to free market among energy providers in Slovenia. They seem to follow well the free market conditions and being flexible to adapt to the intensity of market competition, as well as to increase new customer and new market. This is also supported by the deviation value from past to future period which mostly increased in flexibility. The risks calculated are almost zero and decrease from past to future. This indicates the company is sailing towards the intended direction developed from the beginning.

The network unit does not follow well the free market trend. It remains competing as a prospector group that focuses on quality as their main priority in executing their manufacturing strategy. It is possible due to the dominant ownership of the instrument used for the distribution of electricity in the northwestern part of Slovenia. It is common for a company to belong to a prospector's group in such monopolized environment without many competitors. The risk level calculated is increased to 10 percent from past to the future values and the highest among other companies along the supply chain. This finding suggests the company deviates away from the initial strategy developed by the top management. From the analysis, it is found that the distribution company that works closely with the end customer also does not follow the free market trend. They emphasize more on quality and this made them to be in the prospector group. Even though the risk level is below 10 percent, the values are increasing from past to future. Nevertheless, the deviation value shows that there is an increment in the analyzer strategy from the past to future values. However, the overall value leads this unit to prospector type of strategy.

[14] found the deregulation of the energy market has given some impacts on the dynamics of market competition and demand different management approach as well as quality of service in the supply chain management among electricity providers in Slovenia. Due to the transitions from monopolized market to free market among energy providers in Slovenia, we assumed the business units of case company are moving towards analyzer strategy group which is focused on flexibility and gives a balanced focus on cost, quality and time in order to win bigger market share. We also assumed the distribution unit (sales) is following the best from the new strategy point of view of the free market due to the small gap between their unit and customers or stakeholders along the supply chain. The distribution unit is assumed to understand the market better and react accordingly at their strategy development. However, based from the findings of this research, the only player along the supply chain which is moving towards analyzer group is the production unit. The other two units are still focusing on other priority on implementing their strategy rather than flexibility. As a result, we have identified the manufacturing strategy groups of each business unit according to their manufacturing strategy.

Managerial implications of this study suggest that the allocation of resources should fit the market situation to get a competitive advantage. The results derived from NSCFI, lead to the conclusion both in past and future that can assist managers to review their current business strategy. From the discussion above, this study recommends to operational managers that the allocation of resources should be aligned with the top level management's strategies and to make sure in the future they are following the intended directions. Apart from that, this study also suggests to the managers that paying more attention to identified critical attributes and allocating significant resources properly will improve the overall operational competitiveness. The competitive landscape now has encouraged companies to compete not only on their own capabilities but also with the entire supply chain. Therefore, it is crucial for each of the business unit within the supply chain to align their competitive priorities all across functional areas. For this purpose, this study suggests managers to align competitive priorities with organizational capabilities. Moreover, analytical models used in this study will assist managers to review the current situation of resource allocation for strategy implementation and in case of improvement in the future.

\section{Conclusions}

This paper has analyzed the current and future resource allocations of the case company for sustainable competitive advantage (SCA) using unique analytical models. These models support in decision making of manufacturing strategy development in dynamic and turbulent business environment by taking resources allocation into consideration. Furthermore, this study has determined and analyzed the competitive priorities and manufacturing strategies utilized by the case company in free market conditions to design their operations. The study identifies the critical factors based on past experience and future expectation between different organizational levels. The study has evaluated and suggested significant adjustments of competitive priorities in manufacturing strategies to get operational compet- 
itiveness in free market. In this study, the assumptions were to analyze how different strategy groups are moving towards free market. In the same vein, we presumed that the distribution/sales unit follows the free market. However, this assumption was not met due to lack of allocation of resource in this business unit to fit the analyzer type of strategy.

Knowledge and technology management processes and workflows, organizational system, and information system are the organizational competencies that bring significant value to get a sustainable competitive advantage [59]. Similarly, this study has found most of the critical attributes in knowledge and technology management competency that need to be improved in all business units of the case company. For practice, these approaches have substantial perceptions empirically into the operational competitiveness where competitive priorities should be aligned and configured with allocated resources [67]. In free market situation, every company wants to keep its market share. In this situation, prospectors and defenders groups move towards the analyzer group to get more flexibility and competi- tive advantage. The necessity to prioritize flexibility in their manufacturing strategy still requires further improvement. In conclusion, we argue that resource allocation and manufacturing strategies have become the most important capabilities in business environment where companies focus to get a sustainable competitive advantage.

This study focuses only on the comparison of a business unit operating under one case company. Future research can focus on multiple case studies in different countries to compare the resource allocation with competitive priorities. A large number of informants can provide a better overview of manufacturing strategies and competitive priorities of a company that will ultimately help academia to generalize the overall results. Besides, this study focuses only on three manufacturing strategy types; "prospector", "analyzer", and "defender". Future research can include "reactor" into these types of manufacturing strategies. This promising strategy type can enrich the discussion of manufacturing strategy types and enable competitiveness in turbulent business environment.

\section{Appendix}

\begin{tabular}{|c|c|c|}
\hline Attributes & Competitive Priority & Symbol \\
\hline \multicolumn{3}{|l|}{ Knowledge \& Technology Management } \\
\hline Training and development of the company's personnel & Flexibility & F1 \\
\hline Innovativeness and performance of research and development & Cost & $\mathrm{C} 1$ \\
\hline Communication between different departments and hierarchy level & Time & $\mathrm{T} 1$ \\
\hline Adaptation to knowledge and technology & Flexibility & $\mathrm{F} 2$ \\
\hline Knowledge and technology diffusion & Cost & $\mathrm{C} 2$ \\
\hline Design and planning of the processes and products & Time & $\mathrm{T} 2$ \\
\hline \multicolumn{3}{|l|}{ Processes \& Work Flows } \\
\hline Short and prompt lead-times in order-fulfillment process & Flexibility & F3 \\
\hline Reduction of unprofitable time in processes & Cost & C3 \\
\hline On-time deliveries to customer & Quality & Q1 \\
\hline Control and optimization of all types of inventories & Quality & Q2 \\
\hline Adaptiveness of changes in demands and in order backlog & Flexibility & $\mathrm{F} 4$ \\
\hline \multicolumn{3}{|l|}{ Organizational systems } \\
\hline Leadership and management systems of the company & Cost & $\mathrm{C} 4$ \\
\hline Quality control of products, processes and operations & Quality & Q3 \\
\hline Well-defined responsibilities and tasks for each operation & Flexibility & F5 \\
\hline Utilizing different types of organizing systems & Flexibility & F6 \\
\hline Code of conduct and security of data and information & Cost & $\mathrm{C} 5$ \\
\hline \multicolumn{3}{|l|}{ Information systems } \\
\hline Information systems support the business processes & Time & T3 \\
\hline Visibility of information in information systems & Time & $\mathrm{T} 4$ \\
\hline Availability of information in information systems & Time & T5 \\
\hline Quality \& reliability of information in information systems & Quality & Q4 \\
\hline Usability and functionality of information systems & Quality & Q5 \\
\hline
\end{tabular}




\section{References}

[1] Kim J.S., Arnold P., Operationalizing manufacturing strategy: An exploratory study of constructs and linkage, International Journal of Operations \& Production Management, 16 (12), 45-73, 1996.

[2] Karger C.R., Hennings W., Sustainability evaluation of decentralized electricity generation, Renewable and Sustainable Energy Reviews, 13 (3), 583593, 2009.

[3] Fraser P., Distributed generation in liberalised electricity markets, International Symposium on Distributed Generation: Power System and Market Aspects, pp. 1G-12, 2002.

[4] Si S., Liu Y., Takala J., Sun S., Benchmarking and developing the operational competitiveness of Chinese state-owned manufacturing enterprises in a global context, International Journal of Innovation and Learning, 7 (2), 202-222, 2010.

[5] Boyer K.K., Pagell M., Measurement issues in empirical research?: improving measures of operations strategy and advanced manufacturing technology, Journal of Operations Management, 18 (3), 361$374,2000$.

[6] Christiansen T., Berry W.L., Bruun P., Ward P., A mapping of competitive priorities, manufacturing practices, and operational performance in groups of Danish manufacturing companies, International Journal of Operations \& Production Management, 23 (10), 1163-1183, 2003.

[7] Dangayach G.S., Deshmukh S.G., Practice of manufacturing strategy: Evidence from select Indian automobile companies, International Journal of Production Research, 39 (11), 2353-2393, 2001.

[8] Williams F.P., D'Souza D.E., Rosenfeldt M.E., Kassaee M., Manufacturing strategy, business strategy and firm performance in a mature industry, Journal of Operations Management, 13 (1), 19-33, 1995.

[9] Jabbour C.J.C., Maria da Silva E., Paiva E.L., Almada Santos F.C., Environmental management in Brazil: is it a completely competitive priority?, Journal of Cleaner Production, 21 (1), 11-22, 2012.

[10] Takala J., Kamdee T., Hirvela J., Kyllonen S., Analytic calculation of global operative competitiveness, IAMOT International Conference on Management of Technology, Management of Technology for Service Economy, IAMOT 2007.

[11] Wernerfelt B., A resource-based view of the firm, Strategic Management Journal, 5 (2), 171-180, 1984.

[12] Miles R.E., Snow C.C., Organizational strategy, structure, and process, McGraw-Hill, 1978.
[13] Filippini M., Hrovatin N., Zorič J., Efficiency and regulation of the Slovenian electricity distribution companies, Energy Policy, 32 (3), 335-344, 2004.

[14] Papler D., Bojnec S., Electricity supply management for enterprises in Slovenia, International Journal of Management and Enterprise Development, 4 (4), 403-414, 2007.

[15] Bojnec Š., Papler D., Renewable sources of energy: hydro-electricity in Slovenia, Tehnički Vjesnik, 19 (4), 2012.

[16] Takala J., Liu Y., Feng B., Yang W., Analytical Evaluation of Sustainable Competitive Advantage, Manufacturing Modelling, Management, and Control, 7 (1), 1240-1243, 2013.

[17] Takala J., Shylina D., Forss T., Malmi J., Study on resource allocations for sustainable competitive advantage, Management and Production Engineering Review, 4 (3), 65-75, 2013.

[18] Takala J., Shylina D., Tilabi S., How to Apply Sustainable Competitive Advantage for Regional Developments (Case: Ostrobothnia Region of Finland), Management and Production Engineering Review, 5 (2), 66-77, 2014.

[19] Liu Y., Sustainable competitive advantage in turbulent business environments, International Journal of Production Research, 51 (10), 2821-2841, 2013.

[20] Si S., Takala J., Liu Y., Competitiveness of Chinese high-tech manufacturing companies in global context, Industrial Management \& Data Systems, 109 (3), 404-424, 2009.

[21] Barney J., Firm resources and sustained competitive advantage, Journal of Management, 17 (1), 99-120, 1991.

[22] Barney J.B., Resource-based theories of competitive advantage: A ten-year retrospective on the resourcebased view, Journal of Management, 27 (6), 643-650, 2001.

[23] Santoyo-Castelazo E., Azapagic A., Sustainability assessment of energy systems: Integrating environmental, economic and social aspects, Journal of Cleaner Production, 80, 119-138, 2014.

[24] Ansoff H.I., Corporate strategy: an analytic approach to business policy for growth and expansion, New York: McGraw-Hill Higher Education, 1965.

[25] Porter M.E., The Competitive Advantage of $\mathrm{Na}$ tions, New York: The Free Press, 1990.

[26] Porter M.E., What Is Strategy?, Harvard Business Review, 74 (6), 61-78, 1996.

[27] Boyer K.K., Lewis M.W., Competitive Priorities: Investigating the Need for Trade-Offs in Operations 
Strategy, Production and Operations Management, 11 (1), 9-20, 2002.

[28] Leong G.K., Snyder D.L., Ward P.T., Research in the process and content of manufacturing strategy, Omega, 18 (2), 109-122, 1990.

[29] Ward P., Configurations of manufacturing strategy, business strategy, environment and structure, Journal of Management, 22 (4), 597-626, 1996.

[30] Zhang X., Shen L., Wu Y., Green strategy for gaining competitive advantage in housing development: a China study, Journal of Cleaner Production, 19 (2), 157-167, 2011.

[31] Grant R.M., Contemporary Strategy Analysis, Malden: Blackwell Publishing, 2005.

[32] Takala J., Hirvelä J., Liu Y., Malindžák D., Global manufacturing strategies require "dynamic engineers"?: Case study in Finnish Industries, Industrial Management \& Data Systems, 107 (3), 326-344, 2007.

[33] Mintzberg H., Ahlstrand B., Lampel J., Strategy safari: a guided tour through the wilds of strategic management, Free Press, New York, NY, 10020, 1998.

[34] Van Bommel H., A conceptual framework for analyzing sustainability strategies in industrial supply networks from an innovation perspective, Journal of Cleaner Production, 19 (8), 895-904, 2011.

[35] Seuring S., Müller M., From a literature review to a conceptual framework for sustainable supply chain management, Journal of cleaner production, 16 (15), 1699-1710, 2008.

[36] Kleindorfer P.R., Singhal K., Wassenhove L.N., Sustainable operations management, Production and Operations Management, 14 (4), 482-492, 2005.

[37] Liu Y., Takala J., Modelling and evaluation of operational competitiveness of manufacturing enterprises, Quality Innovation Prosperity, 13 (2), 1-19, 2009.

[38] Liu Y., Liang L., Evaluating and developing resource-based operations strategy for competitive advantage: an exploratory study of Finnish high-tech manufacturing industries, International Journal of Production Research, 53 (4), 1019-1037, 2015.

[39] Haeckel S.H., From "make and sell" to "sense and respond", Management Review, 81 (10), 3-9, 1992.

[40] Bradley S.P., Nolan R.L., Sense and Respond: Capturing Value in the Network Era, Harvard Business School Press, 1998.

[41] Markides C., All the right moves: a guide to crafting breakthrough strategy, Harvard Business Press, 2000 .
[42] Liu Y., Takala J., Operations strategy optimization based on developed sense and respond methodology, Journal on Innovation and Sustainability, RISUS ISSN 2179-3565, 3 (1), 2012.

[43] Ranta J.M., Takala J., A holistic method for finding out critical features of industry maintenance services, International Journal of Services and Standards, 3 (3), 312-325, 2007.

[44] Nadler D., Takala J., The development of the CFI method to measure the performance of business processes based on real life expectations and experiences, International Conference on Innovation and Management, ICIM2010, December, pp. 4-5, 2010.

[45] Porter M.E., Competitive strategy: Techniques for analyzing industries and competitors, New York, Free Press, 1980.

[46] Porter M.E., Competitive advantage: creating and sustaining superior performance, The Free Press, NY, 1985.

[47] Peters T.J., Waterman R.H., In Search of Excellence: Lessons from America's Best-Run Companies, New York: Harper \& Row, 1982.

[48] Peters T.J., The Little Big Things: 163 Ways to Pursue Excellence, New York: HarperCollins, 2010.

[49] Hayes R.H., Wheelwright S.C., Restoring Our Competitive Edge: Competing Through Manufacturing, New York: John Wiley \& Sons, 1984.

[50] Hayes R.H., Wheelwright S.C., Clark K.B., Dynamic Manufacturing: Creating the Learning Organization, New York: Free Press, 1988.

[51] Avella L., Fernandez E., Vazquez C.J., Analysis of manufacturing strategy as an explanatory factor of competitiveness in the large Spanish industrial firm, International Journal of Production Economics, 72 (2), 139-157, 2001.

[52] Barney J., Wright M., Ketchen D.J., The resourcebased view of the firm: Ten years after 1991, Journal of Management, 27 (6), 625-641, 2001.

[53] Liu Y., Implementing Sustainable Competitive Advantage for Proactive Operations in Global Turbulent Business Environments, University of Vaasa, Department of Production, 2010.

[54] Day G.S., Wensley R., Assessing advantage: a framework for diagnosing competitive superiority, The Journal of Marketing, 52 (2), 1-20, 1988.

[55] Grant R.M., Analyzing resources and capabilities, In R.M. Grant [Ed.], Contemporary Strategy Analysis: Concepts, Techniques, Applications, Malden: Blackwell, pp. 93-122, 1991. 
[56] Hall R., A framework linking intangible resources and capabilities to sustainable competitive advantage, Strategic Management Journal, 14 (8), $607-$ 618, 1993.

[57] Fiol C.M., Revisiting an identity-based view of sustainable competitive advantage, Journal of Management, 27 (6), 691-699, 2001.

[58] Fahy J., A resource-based analysis of sustainable competitive advantage in a global environment, International Business Review, 11 (1), 57-77, 2002.

[59] Lubit R., The keys to sustainable competitive advantage: Tacit knowledge and knowledge management, Organizational Dynamics, 29 (3), 164-178, 2002.

[60] Johannessen J.A., Olsen B., Knowledge management and sustainable competitive advantages: The impact of dynamic contextual training, International Journal of Information Management, 23 (4), $277-$ 289, 2003.

[61] Ren L., Xie G., Krabbendam K., Sustainable competitive advantage and marketing innovation within firms: A pragmatic approach for Chinese firms, Management Research Review, 33 (1), 79-89, 2009.

[62] Toor S.U.R., Ofori G., Positive psychological capital as a source of sustainable competitive advantage for organizations, Journal of Construction Engineering and Management, 136 (3), 341-352, 2009.

[63] Hosnar J., Kovač-Kralj A., Mathematical modelling and MINLP programming of a hydro system for power generation, Journal of Cleaner Production, 65, 194-201, 2014.

[64] Kasanen E., Lukka K., The constructive approach in management accounting research, Journal of Management Accounting Research, (5), 243-264, 1993.

[65] Piirainen K.A., Gonzalez R.A., Constructive Synergy in Design Science Research: A Comparative Analysis of Design Science Research and the Constructive Research Approach, Liiketaloudellinen Aikakauskirja, (3-4), 206-234, 2014.

[66] Vuoti V.P., Takala J., Mäntylä A., Liu Y., Yang W., Malek N.A.B.A., Zafar A., Validating performance based critical actions in a high tech start-up, Proceedings of 2013 International Conference on Technology Innovation and Industrial Management (pp. 109-124), Phuket, Thailand: Technology Innovation and Industrial Management 2014.

[67] Maylor H., Turner N., Murray-Webster R., It worked for manufacturing...!: Operations strategy in project-based operations, International Journal of Project Management, In Press, 2014. 